\title{
Thyroglobulin Measurement
}

National Cancer Institute

\section{Source}

National Cancer Institute. Thyroglobulin Measurement. NCI Thesaurus. Code C103446.

The determination of the amount of the thyrog lobulin in a sample. 